\title{
Forms of cooperation of government, business and science to create innovative sectors of economy (regional aspect)
}

\author{
Nikitenko Sergey Mihailovich \\ Department of Economics \\ Plekhanov Russian University of Economics \\ Kemerovo, Russian Federation \\ nsm.nis@mail.ru \\ Pakhomova Elena Anatolievna \\ Department of Economics \\ Dubna International University \\ Dubna, Russian Federation
}

\author{
Goosen Elena Vladimirovna \\ Department of economic theory and public administration \\ Kemerovo State University \\ Kemerovo, Russian Federation \\ egoosen@yandex.ru \\ Rozhkova Olga Vladimirovna \\ Department of Economics \\ Dubna International University \\ Dubna, Russian Federation
}

\begin{abstract}
The article is devoted to the existing forms of government, business and science cooperation in innovation economy sectors at the regional level and to the possibilities of applying the concept of "triple helix" and its multi-helix modifications. Russia needs a correction of economic imbalances, improving the institutional environment and reforming the system of regional development management. The article reveals the most perspective forms of interaction of government and business: agreements on public-private partnership, concession agreements, special investment contracts. The key issues of embedding science in these chains are specified and the solutions to these problems are proposed. Changes in Russia will require overcoming the existing gaps in three dimensions: firstly, at the level of education and science where an innovative generation (people with imagination) should be formed. Secondly, at the enterprise level, where changes will require building the relations between fundamental and applied interdisciplinary research on the one hand and introduction of the developments into production on the other hand, contributing to the achievement of a balance between international innovation and tradition. Finally, at the level of the society consumer confidence and domestic demand should be developed, stimulating new developments and implementations. The article was prepared with the financial support of the Russian Foundation for Basic Research (project No. 16-06-00054 "The Instrumental and Methodological Approach to Adapting the Triple-Helix Model to the Russian Conditions in Line with Historical Retrospects").
\end{abstract}

Keywords-“triple helix" model, resilient regions, cooperation, public-private partnership

\section{INTRODUCTION}

International approaches to the solution of territorial formations problems, caused by raising regions' role and empowerment due to institutional and resource selfsufficiency, are based on the sustainable development paradigm, aimed at improving population living standards under the positive dynamics of interrelated economic, social, environmental, and other indicators.

The spread of information technologies has complicated the spatial organization of economic systems and brought to the foreground the horizontal and network type of cooperation which is more flexible than the hierarchical interaction with the traditional administrative approach, and more open and focused on collaboration, cooperation and integration than the "individualized" competitive market economy [1]. Unlike competition, inevitably leading to concurrent use of resources, aimed at achieving mutually exclusive goals and, therefore, resulting in wasteful spending of resources, cooperation involves harmonization of efforts [2]. The increasing role of cooperation institutions is a natural outcome of the technological, cultural and institutional evolution.

In connection with the development of communication opportunities with relatively low costs, which previously would require a larger effort on the part of market actors [3], the structure is being changed. The alteration of the society's role, the increase in the rate of consumer expectations and preferences changing, the formation of the consumer and domestic demand stimulating new developments and implementations influence the economic environment and the proliferation of new goods and values.

The article is aimed at the investigation of government, business and science cooperation in innovation economy sectors at the regional level.

The authors chose H. Etzkowitz and L. Leydesdorff's concept of "triple helix" its multi-helix modifications (expanded models of innovation processes) as the methodological base for comprehensive analysis of economic systems and models that have sufficient empirical basis. Basing on that concept, one can describe the dynamics of many national institutional arrangements, their relations in 
face of uncertainty with other factors, political and social development and the "traps" of the interaction. The key features of the chosen concepts are: the ability to compromise between differentiation and integration of components, "a field" for changing of the participants of interactions and relationships, and strengthening of the effect in the context of communication theory $[4,5,6,7]$.

\section{RESULT AND DISCUSSION}

The founder of the evolutionary economy, J. Schumpeter, suggested that changes within the economic system are due to the emergence of innovations. However, innovations can be destructive - they do not only lead to changes, but also make the system more fragile and unstable. The neoclassical theory of the firm, proceeding from an individualistic approach and explaining the behavior of the subjects, based on the maximization of income, does not provide the answer to the question of how to ensure the introduction of innovations within the framework of innovative processes while maintaining the stability of the system. The answer to it can be found in the framework of the new institutional evolutionary approach proposed by R. Nelson and S. Winter. Using dynamic development models, they described the behavior of the firm that develops and implements innovations. G. Itskovich used their theory the model of the "triple helix", showing the role of universities, business and the state in modern national and regional systems, and also showing the nature of their interaction, describing the life cycle of innovation, and explaining the causes and channels for the transformation of new knowledge into innovation. An important aspect of G. Itskovich's research is the problem of cooperation of subjects that belong not only to different spheres, but also operate in different fields, on the basis of excellent rules. These three key elements of G.I. Iskowitz's theory (innovations, cooperation, regional innovation system) make it extremely relevant to apply this concept to the study of innovation processes in the Russian regions.

In the 2000s, this model was actively implemented in the economic practice of developed countries as a methodological basis for the formation and organization of regional innovation systems. On its basis, there were being created clusters, industrial parks, centers of competence and others. G. Itskovich's research allowed collecting a significant empirical material on the basis of the experience of developed countries. Russian economists based on G. Itskovich's research to develop verbal models, describing the features of the innovation process in Russia and its regions.

It is clear that such experience in its pure form may not be transferred to the Russian ground. The nature of Russian integration processes are mixed, due to a number of reasons: institutional and regulatory instability, the contradictory goals and conflicts of economic agents, unequal access to production factors, weak management mechanisms, the threat of markets monopolization, poor property rights protection, the relatively low level of business culture.

In this regard, Russia's peculiarities require removing economic imbalances, improving the institutional environment and reforming the system of regional development management system, namely: formation of common priorities; identification and support of economic agents in local communities, scientific or business environment; commercialization and spreading of innovation processes; implementation of mechanisms for coordination and control over activities and change in functions and areas of participants' responsibility [7].

Considering the region as the central element in the transformation, the authors set a task to identify key hierarchical levels of regional "pyramid of innovations":

- innovation environment;

- innovation processes;

- mechanisms for the societal needs implementation;

- innovative activity and measures for its promotion (credits as one of the institutional determinants of consumer demand, tax and customs benefits, insurance and intellectual property protection tools);

- results and economic consequences of innovation for the subsequent filling with mathematical tools that allow quantifying and identifying "weak links", and the proposals for structural change adapted to different formats of interaction among three main "blocks": the state, research and education institutions, and business and society that are united on the basis of the industry's strategic objectives and traditional links, financing, the degree of mutual influence and other factors (including life-cycle stage) [5].

Such enterprises can take many forms and include knowledge institutions, financial and government institutions, system integrators, manufacturers and/or suppliers of technologies, equipment and raw materials, and manufacturers of finished products supervising the production, etc. Table 1 shows the examples of the most common contractual forms.

TABLE I. THE MOST COMMON CONTRACTUAL FORMS OF GOVERNMENT, BUSINESS AND SCIENCE COOPERATION IN INNOVATION SPHERE

\begin{tabular}{|l|l|}
\hline \multicolumn{1}{|c|}{$\begin{array}{c}\text { Form of } \\
\text { interaction }\end{array}$} & \multicolumn{1}{|c|}{ Features of interaction } \\
\hline \multirow{5}{*}{$\begin{array}{l}\text { Concession } \\
\text { agreement }\end{array}$} & $\begin{array}{l}\text { Under the concession agreement one party } \\
\text { (concessionaire) undertakes the duty to create } \\
\text { and (or) to reconstruct the property defined by } \\
\text { this agreement, (real estate or immovable } \\
\text { property and movable property technologically } \\
\text { interconnected and intended for the } \\
\text { implementation of activities under the } \\
\text { concession agreement) (hereinafter the object of } \\
\text { the concession agreement) at its own expense. } \\
\text { The property is owned by another party (the } \\
\text { confident), while the concessionaire can use } \\
\text { (operate) the object of concession agreement. } \\
\text { The concessionaire shall provide the } \\
\text { concessionaire the rights to possess and use the } \\
\text { object of concession agreement for a period } \\
\text { specified in this agreement for the } \\
\text { implementation of these activities. }\end{array}$ \\
\hline
\end{tabular}




\begin{tabular}{|c|c|}
\hline $\begin{array}{l}\text { The agreement on } \\
\text { public-private } \\
\text { partnership (PPP) }\end{array}$ & $\begin{array}{l}\text { Under the agreement the private partner should } \\
\text { to create some immovable property or } \\
\text { immovable property and movable property fully } \\
\text { or partially at their own expense or with } \\
\text { borrowed funds. The property should be } \\
\text { technologically interconnected and intended for } \\
\text { the implementation of activities under the } \\
\text { agreement. The private partner should operate } \\
\text { and (or) maintain such property, and the public } \\
\text { partner agrees to provide the private partner the } \\
\text { right of its possession and use for the } \\
\text { implementation of the agreement activities. The } \\
\text { public partner should also ensure private } \\
\text { partner's right of ownership of the object of the } \\
\text { agreement, subject to the requirements of the } \\
\text { Federal law and the agreement. Under the } \\
\text { agreement, the parties also are to perform other } \\
\text { obligations that arise from elements of the } \\
\text { agreement defining the form of public-private } \\
\text { partnership. }\end{array}$ \\
\hline $\begin{array}{l}\text { Special investment } \\
\text { contracts (SIC) }\end{array}$ & $\begin{array}{l}\text { Special investment contracts (SIC) are } \\
\text { introduced by the Federal law "On industrial } \\
\text { policy in the Russian Federation". The industry } \\
\text { development fund acts as the operator at the } \\
\text { conclusion of the ACNP. A special investment } \\
\text { contract is an agreement between the investor } \\
\text { and the Russian Federation (or its subject), which } \\
\text { records the obligation of the investor (to master } \\
\text { the production of industrial products within the } \\
\text { scheduled time) and the obligation of the Russian } \\
\text { Federation (or its subject): to guarantee the } \\
\text { stability of tax and regulatory conditions and to } \\
\text { provide incentives and support. The validity of } \\
\text { SIC is equal to the term of the project's operating } \\
\text { profit plus } 5 \text { years, but not more than } 10 \text { years. }\end{array}$ \\
\hline $\begin{array}{l}\text { Grants, budget } \\
\text { investments, } \\
\text { budget credits, } \\
\text { state job }\end{array}$ & $\begin{array}{l}\text { Various forms of (paid and free) budget } \\
\text { financing of scientific research are allotted for } \\
\text { the implementation of medium-term projects of } \\
\text { the Federal program }\end{array}$ \\
\hline
\end{tabular}

According to the statistics, the concession agreements were the most widely spread; there are 22 projects in Russia at the regional level in the exploitation phase. According to official statistics, there are no agreements on public-private partnerships, which is due to regulatory changes in the Law on Public-Private Partnership 2015, but the projects of quasi-PPP of the regional level are hundreds of times larger than the number of classical public-private partnership projects. These are various programs and projects for the integrated development of territories, rational use of natural resources, creation of points for accelerated growth. The projects are also aimed at creating territories for advanced development, infrastructure projects fully funded from budgetary funds, joint ventures, agreements of government and business on socio-economic development, state and regional orders, etc. In many regional PPP laws, infrastructure projects, implemented on the basis of state contracts and agreements on social and economic cooperation between regional and business administrations, as well as federal and regional target programs, are referred to as PPP projects. Separate regions even include ordinary business support programs into PublicPrivate Partnership.

In a region like Kemerovo region, the quasi- Public-Private Partnership has acquired the form of concluding agreements on interaction and socio-economic cooperation (partnership) between the regional administration and owners of coal companies - the main investors in the economy of the regions.
Business structures are supported by regional authorities for their presence in the region. In turn, the regional government ensures stability of the situation in the region through the agreements on social and economic cooperation. Within the framework of the agreements, the issues of infrastructure development in the regions are being resolved, employment is supported, and social programs are being financed, which have always been underfunded from the national level. In fact, the agreement on socio-economic cooperation substitutes not only Public-Private Partnership projects, but also industrial policy and the policy of regional development. Kemerovo Region is one of the most representative regions in terms of the use of agreements on socio-economic cooperation as an instrument of the region's development policy.

By 2017, 8 special investment contracts have been concluded in Russia, and another 10 are under consideration. The biggest numbers of special investment contracts are in Leningrad Region and Moscow Region. As of May 1, 2017, 68 out of 85 subjects of the Russian Federation have a separate normative act defining the rules and procedure for concluding a SPIC on behalf of the entity, which formed regional differences.

Conventionally, the introduction of a special investment contract instrument can be divided into two areas: the first is the adoption of an act specifying additional conditions for concluding a special investment contract. In such entities, the rules do not contain new conditions for concluding a special investment contract; they repeat federal requirements (15 regions). And the second direction is connected with the formation of requirements for an investor to participate in a special investment contract. These include the volume of investment, the number of jobs, annual revenue.

The rules and the procedure for concluding a special investment contract prescribe the required amount of investment, which is often smaller than stated in the requirements of the federal legislation (750 million rubles), whereas the number of seats and revenue is not regulated by the federal legislation. The volume of investments in the amount of less than 750 million rubles is represented in 36 regions of the Russian Federation, the smallest volume is in the Republic of Khakassia $(10$ million rubles for the conclusion of a special investment contract in Chernogorsk), and in 5 Russian regions of the Federation (Altai Krai, Sevastopol, Bryansk region, Ivanovo region, Ryazan region) the amount is 50 million rubles. The increased volume of investments is observed in Moscow region, where the amount of investment is set at 1 billion rubles. The largest amount of investment (1.5 billion rubles) has been observed in Kaliningrad region over 3 years. It should be noted that in the Kaliningrad region, priority investment projects include investment projects implemented by residents of the special economic zone. Such conditions allow attracting large investors, giving them a choice of support programs and other mechanisms for attracting investments.

In seven regions of the Russian Federation (the Altai Krai, the Republic of Komi, Udmurt Republic, the Republic of Chuvashia, Perm Krai, Orenburg Region, are Saratov Region), the requirements for the number of workplaces created have 
been established. The smallest number is in Altai Republic and Orenburg region (50 workplaces remaining until the end of the project), while in Perm Krai and Orel - 250 workplaces should be created.

In Saratov region, the investor is given a choice: either to invest the amount of at least 400 million rubles, or to invest 50 million rubles and a sign the obligation to create at least 100 new work places during the implementation of the investment project and to preserve them until before the end of the term.

The advantages of SICs for investors are great, since a SIC is signed for a Russian product, with the only supplier and tax incentives. For government is an instrument for attracting investments, localizing the investor on its territory with a 10 year guarantee, creation of new workplaces and no necessity of budget investment. It also means the creation of a new product in the economy with the subsequent development of service industries.

Special investment contract as a development tool has comparative advantages and can become a full-fledged form of cooperation between government and business in the fuel and energy sector.

According to the internal costs of research and development of 10 regions of leaders (according to the Russian statistics department), it looks like this:

1. Moscow region - 111318.2 million rubles.

2. Moscow - 322,785.1 million rubles.

3. St. Petersburg - 109711.5 million rubles.

4. Rostov region - 13682.2 million rubles.

5. The Republic of Tatarstan - 12202.2 million rubles.

6. Perm Territory - 12944.6 million rubles.

7. Nizhny Novgorod region - 65584.1 million rubles.

8. The Samara region - 17,353.3 million rubles.

9. Sverdlovsk region - 26,259.1 million rubles.

10. Tyumen region - 14171.8 million rubles.

Most regions' high rankings in the rating are due to two factors: firstly, the territory itself. Availability of universities, academic towns, science cities, all kinds of research institutes, design bureaus, scientific and production associations that provide the theoretical basis of innovation and technological development. Secondly, the presence in the region of historically developed high-tech by any world standards of nuclear and military industry or with the operation of special economic zones and relatively new automotive clusters that provide a platform for the introduction of theoretical research in practice. In this regard, it is not surprising to find the top ten, along with the metropolitan regions of the Tomsk region, on whose territory the research centers of state scale are located.

The Chukotsky Autonomous Okrug closes the rating on the volume of scientific support - 39.2 million rubles, in which, due to historical and geographical reasons, there is no scientific and research environment, and there is little or no high-tech or even mid-technological processing industry.

Thus, the regions use different forms of interaction in different ways and have different conditions for their implementation.

Forms of government, business and scientific-educational institutions cooperation can be simple or complex. Structural elements in such alliances can be as: a commercial affiliation program, the production of goods under license, joint research and development, joint procurement, investment projects, enterprises, unions and associations, clusters, markets, industries, regions, etc. The lists of participants and their roles (and thus strategies) are constantly changing [8], which reduces the importance of rigid designation of boundaries for those communities for a long period, highlighting the following problems:

- choice and analysis of the environment, which most closely is associated with the strategic objectives achievement;

- relationships definition;

- interaction processes "contact points" control.

- such forms are difficult to compare, to develop the criteria of effectiveness and efficiency.

A serious problem for the regional innovation systems development is a vertical system of cooperation between the state and scientific organizations, inherited from the Soviet Union. In the period of market transformations these problems were added by a mismatch between supply and demand on the scientific product division, base for researching and professional training, lack of science and technology policies coordination, the distribution between a number of weakly coordinating ministries and agencies, uneven financial flows and so on do not contribute to the true priorities and socioeconomic sustainability. All this leads to the fact that the regional innovation system forming is extremely slow, contradictory and spontaneously.

Historically, the closest links have formed with the research structures assigned to certain departments, primarily belonging to the commodity sector of the economy, which is the one the state gives sustainable preference to. At the same time, Russian major business does not show sufficient level of activity and merging with the state leads to lobbying of local interests and reduces the overall efficiency, despite high incomes and international markets competitiveness $[9,10,11]$. Tab. 2 shows the data on the structure of the agreements of the largest Russian oil and gas companies - Public Joint Stock Company Gazprom.

The data given in the table eloquently testify the weak commitment of the company to participate in the regional innovative projects. Of the 61 region with which PJSC Gazprom signed a variety of cooperation agreements, only in 2 regions (Tomsk and Omsk regions) there are signed a Memorandum of cooperation in the sphere of the regional educational and industrial center organizing and functioning and an Agreement on scientific-technical cooperation and 
partnership, aimed directly at the regional innovation systems development. Intermediate between cooperation agreements aimed at maintaining the investment and income in the region, and agreements aimed at regional innovative development are roadmaps, or the projects aimed at expanding the use of hightech products of regional science-intensive organizations in the interests of "Gazprom. They contain the plan and the stages of development of high-tech industries in the regions, local producers are involved, the examination and certification of products. In some regions, the roadmaps are involved in scientific and educational organizations. However, their number is not large, only 10 [12].

TABLE II. THE MAIN TYPES AND THE NUMBER OF AGREEMENTS CONCLUDED BY PJSC GAZPROM AND REGIONAL AUTHORITIES IN 2017

\begin{tabular}{|l|l|}
\hline \multicolumn{1}{|c|}{ The types of agreement } & \multicolumn{1}{|c|}{$\begin{array}{c}\text { The number } \\
\text { of regions }\end{array}$} \\
\hline Cooperation agreements (long- and short-term) & 61 \\
\hline $\begin{array}{l}\text { The agreement on wider use of natural gas as motor } \\
\text { fuel }\end{array}$ & 61 \\
\hline The program "Gazprom - to children" & 61 \\
\hline $\begin{array}{l}\text { Road map of the project "Expanding the use of high- } \\
\text { tech products of regional science-intensive } \\
\text { organizations, including import substitution, in the } \\
\text { interests of "Gazprom" }\end{array}$ & 43 \\
\hline $\begin{array}{l}\text { Memorandum of cooperation in the sphere of the } \\
\text { regional educational and industrial center organizing } \\
\text { and functioning }\end{array}$ & 2 \\
\hline $\begin{array}{l}\text { The agreement on scientific and technical cooperation } \\
\text { and partnership (2016-2020) }\end{array}$ & 2 \\
\hline \begin{tabular}{l} 
In general assessing the degree of the basic entities \\
\hline
\end{tabular}
\end{tabular}
(components of the triple helix) interaction development, it should be recognized that the interaction between the scientific and the business environment appears to be the most problematic. This is caused by a number of objective and subjective factors, among which the applied sciences backwardness is the most important.

To evaluate the relationship between business and other elements (state and society) as well is quite difficult, but as the overall institutional environment has not yet formed adequately, and is not favorable, one can say that the existing format of the relationships is qualitatively different from the one that adopted in foreign countries.

A significant place in the socio-economic development of constituent entities of the Russian Federation is given to the arrangement of the clusters, since they allow one to move away from the previously dominant approach in the orientation exclusively on high-tech industry, to stimulate research and development to accelerate the processes of creation and diffusion of innovations through the formation of stable ties between science, business and local authorities. These relations have a decisive influence on the frequency and speed of propagation of innovation and competitiveness $[13,14,15]$

For qualitative and quantitative assessment of innovation activity the authors developed a list indicating any trends in the structural indicators, distributed in three groups: an innovative component for economic growth; the investment component for the development in the long term; component of sustainable development, ensuring the growth of competitiveness and quality of life. Through econometric modelling the peculiarities of the development of the national industry structure for different public organizations historical periods that have allowed to develop additional indicators and to offer methods of measurement in order to assess the effectiveness of ongoing reforms in the country.

Recommendations for systematic upgrading of aspects of the socio-economic system developed by the authors based on the functional economic and mathematical models and lay the foundations for a unified approach ("designer") in the formation of resilient regions, regardless of geographical, social etc. differences.

In the study, the establishment and functioning of national innovation systems and approaches are of interest: the global experience, developed on the basis of various factors and the concept of "triple helix" of national forms of interaction of elements that contribute to the development of both fundamental and applied research of an interdisciplinary nature, the emergence of start-ups, variety of entrepreneurial universities and science parks.

A deep analysis of the "Euro-Atlantic", "Asian", "alternative" and other models can be the basis for the development of Russian regional ecosystems, taking into account local specificity and "smart specialization" in order of greatest contribution to socio-economic development.

By now there have been received a number of conceptual and applied results of the "triple helix" model research that take into account both the global and Russian economic realities, and historical retrospectives, which is the base for the current state and a number of inherited elements of economic activity.

The conceptual results, clarifying a number of provisions required to adapt the model of "triple helix" to domestic conditions are as follows:

- the analysis of the empirical base of the model identifying the structural units, their substantive content, the development schemes of their cooperation in the area of cross-section;

- the study the possibility of initiating the process of interaction of any party structure in the model;

- the allocation of favorable conditions for development in the triple interaction.

In general, the authors identified through econometric modeling features of development of economy of Russia in different public organizations historical periods. And fragments have received a possible economic interpretation of the role and structural proportions of the industry in socioeconomic development and inconsistencies of modern economic policy that creates the real basis for further use of existing indicators and suggestions and development of additional ones for methods of measurement to assess the effectiveness of ongoing reforms in the country.

Full ecosystem restructuring in the Russian context will require the overcoming of existing gaps in three dimensions: at the level of education and science - to form innovative 
generation ("people with imagination"); at the enterprise level - in order to build the relationship between the development of fundamental and applied research of an interdisciplinary nature and implementation of developments in production, contributing to the achievement of a balance between international innovations and home traditions; at the level of society - to create consumer confidence and domestic demand, stimulating new developments and implementations.

\section{CONCLUSION}

The result of set in this article the problems of application of the triple helix model and its modifications in the Russian context can be formulated as follows. A priority approach should be a refusal of domination by any side in favor of transformation of the state control ways and methods, higher adaptability of the regional authorities and stimulating all types of events, aimed at a variety of economic agents.

The implementation of the principles of the "triple helix" element of the "state" can be realized as follows:

- at the federal level, there are the functions of determination of priorities of innovation activities and creation of institutional preconditions for its development; management and financing of innovation activities (including such forms as the state order, tender or grant); the development of innovative policies and methods, models and tools for its implementation, including the development of virtual networks; the establishment of mechanisms of commercialization of knowledge and the organization of international cooperation in this field;

- at the regional level, there are the creation of an appropriate infrastructure; establishment of integrated service centers with the participation of all stakeholders, with sufficient generation capacity development on the basis of key regional competencies, providing information, consulting, investment, branding support, technology transfer, strategic and operational management of innovation chains design.

Summing up, it should be emphasized that:

- network format, founded in the model of "triple helix", on the basis of the principle of consent and cooperation contributes to the integral effect of continuous updates;

- for Russia, foreign experience of the concept introduction can contribute to identifying and selecting the most promising forms of multilateral regional cooperation in matters of disclosure implicit opportunities for the development of new comparative advantages of regions, use of innovation, adapted to the conditions of the regions, development of the internal market and closer interregional cooperation [15].

- organization mechanisms of the innovation management need to be based on the network interaction innovation-based factors with the goal of transformation costs in a much larger-scale socioeconomic impact at the level of individual enterprises and at the level of industries, regions, and states;

- social activity is another resource of competitiveness improvement;

- in conditions of intensified competition and changing patterns of consumer behavior, the key parameter is the rate of the innovation cycle reproduction;

- in any space, a special "ecological environment" can be formed, which includes mutual expectations and requirements of the elements and permits adaptation of the old forms of economic entities to new conditions at the micro-, meso-, macro levels.

\section{References}

[1] N.V. Smorodinskaja, "The triple helix as a new matrix for economic systems", Innovations, vol. 4, pp 66-78, 2011.

[2] V.M. Polterovich, "From social liberalism to the philosophy of cooperation”, Social Sciences And Modernity, vol. 4, pp. 41-64, 2015.

[3] A.A. Krupanin, Ju.V. Mjachin, Ju.I. Rastova, Management problems of modernization, Saint-Petersburg: Russia, 2011, 236 p.

[4] H. Etzkowitz, L. Leydesdorff, "The triple helix of university-industrygovernment relations: a laboratory for knowledge-based economic development”, EASST Review, vol. 14, pp. 14-19? 1995

[5] E. Carayannis, E. Grigoroudis, "Quadruple Innovation Helix and Smar Specialization: Knowledge Production and National Competitiveness", Foresight and STI Governance, vol. 10, no 1, pp. 31-42, 2016.

[6] D. Foray, X. Goenaga, "The goals of Smart Specialization: S3 policy brief series", JRC Scientific and Policy Reports, 2013 [Brussels: European Commission]

[7] C. Leonard, "Spatial Development and Innovation in Russia", Foresight and STI Governance, vol. 10, no 3, pp. 30-33, 2016.

[8] S.M. Nikitenko, L.P. Patrakova, E.V. Goosen, "Implementation of joint innovation projects of business and local authority as a factor of sustainable economic development of municipal education", Regional economy: theory and practice, vol. 24, pp. 17-26, 2009.

[9] S.M. Nikitenko, E.V.Goosen, "The problems and prospects of the public-private partnership in the russian fuel and energy sector", IOP Conf. Series: Earth and Environmental Science 53, 012018, DOI:10.1088/1755-1315/53/1/012018, 2017 [All-Russian Conference on Challenges for Development in Mining Science and Mining Industry devoted to the 85th anniversary of Academician Mikhail Kurlenya 3-6 October 2016, Novosibirsk, Russia]

[10] A.E. Kontorovich, L.V. Eder, V.Yu. "Nemov, Oil and gas in the Russian economics", Neftyanoe khozyaystvo - Oil Industry, Issue 1, pp. 4-8, 2013.

[11] A.G. Korzhubaev, I.V. Filimonova, L.V. Eder, I.A. Sokolova, "Strategy of development of an oil-and-gas complex Siberia", Neftyanoe khozyaystvo - Oil Industry, Issue 3, pp. 14-17, 2009.

[12] Official site «Gazprom» http://www.gazprom.com/about/

[13] Yu.S. Artamonova, B.B. Khrustalev, Cluster policies and cluster initiatives: theory, methodology, practice, Penza 2013, 227p.

[14] E. S. Kutsenko, E. Islankina, V. L. Abashkin "The evolution of cluste initiatives in Russia: the impacts of policy, life-time, proximity and innovative environment", Foresight, vol. 19, no. 2, pp. 87-120, 2017.

[15] S. Zemtsov, V. Barinova, A. Pankratov, E. Kutsenko, "Potential HighTech Clusters in Russian Regions: From Current Policy to New Growth Areas", Foresight and STI Governance, vol. 10, no. 3, pp. 34-52, 2016. 